\title{
AN EXPLANATION FOR AND EXPERIMENTAL CORRECTION OF THE ABNORMAL WATER DIURESIS IN CIRRHOSIS *
}

\author{
By HAROLD P. SCHEDL $†$ AND FREDERIC C. BARTTER \\ (From the Section on Clinical Endocrinology, National Heart Institute, Bethesda, Md.)
}

(Submitted for publication June 30, 1959; accepted October 1, 1959)

It is well established that certain patients with hepatic cirrhosis show impaired water diuresis following water loads (1). With this limitation in free water excretion, hyponatremia may develop on average water intakes. It has been asserted and denied that antidiuretic hormone (ADH), secreted in excess or inadequately inactivated, is responsible for the water retention $(2,3)$. In this study the role of antidiuretic hormone in cirrhosis is reexamined. The results do not support the concept that it plays the primary role in the retention of water.

Since free water is presumably produced by the reabsorption of sodium $(4,5)$, these patients present a paradox in that they show almost quantitative reabsorption of filtered sodium. The paradox could be resolved by postulating that proximal tubular sodium reabsorption in these subjects is so great as to allow little sodium to pass to the distal site where free water is generated. It follows $a$ ) that the defect should be corrected by delivery of proximal tubular fluid into the distal tubules and $b$ ) that normal subjects should show a similar "defect" correctable by the same process when depleted of sodium. In the present study these propositions are examined.

\section{SUBJECTS AND METHODS}

Eight normal subjects and 8 patients with cirrhosis were maintained in an air-conditioned environment in a metabolic ward. They were fasted, and fluids were withheld after 6:00 p.m. the day prior to the tests. On the day of the study they were weighed at 7:30 a.m. and water loads ( $20 \mathrm{ml}$ per $\mathrm{kg}$ ) were drunk in approximately 1 hour, or infused intravenously in 1 to 1.5 hours. Overnight urine specimens were collected from 10:30 p.m. on the previous day to 7:30 a.m. On the day of the study to provide an estimate of the state of hydration of the sub-

* Presented at the National Meeting of the American Federation for Clinical Research, Atlantic City, N. J., May 4, 1958.

+ Present address: Dept. of Medicine, State University of Iowa College of Medicine, Iowa City, Iowa. ject in each study. In each case where direct comparisons were made between studies in a given subject, the volumes of these specimens were within $100 \mathrm{ml}$ of each other and their concentrations were within $95 \mathrm{mOsm}$ per $\mathrm{kg}$. On the day of the test, voided urine specimens were collected from 7:30 a.m. to 8:30 a.m. and at intervals of 10 minutes to 1 hour thereafter, collections being made as frequently as the subject could void. Urine collection was concluded at 12:30 p.m. Subjects were recumbent (head on one pillow) during all studies, except when standing to void. "Arterialized" venous blood samples were drawn $a$ ) just prior to loading; $b$ ) 1 hour after the oral load had been drunk, or 15 minutes after the end of the infusion, from a needle in the opposite arm; and $c$ ) between 12:00 and 12:30. To help assure constancy of hydration, the subject's ordinary fluid intake was determined before studies were begun and was maintained thereafter on the day prior to studies, with one exception : Subject A.N. received $2,000 \mathrm{ml}$ additional water daily while sodium-depleted. At least 48 hours intervened between the beginning of successive studies. Normal subjects receiving a low sodium diet were further depleted of sodium by administration of $2 \mathrm{ml}$. of Thiomerin sodium intramuscularly after they had taken 5 to $15 \mathrm{~g}$ of ammonium chloride daily for 2 or 3 days. Studies were not done until 3 days had elapsed after the last injection of mercurial. Unless otherwise indicated, all patients with cirrhosis were studied on a sodium intake of 9 $\mathrm{mEq}$ per day for therapeutic reasons. They were partaking of adequate amounts of an otherwise normal diet, except for N.K., who refused some food. All showed essentially quantitative retention of ingested sodium despite marked excess of total body sodium as demonstrated by collection of copious ascitic fluid. In some studies, sustained rather than acute water diuresis was studied. The subject was allowed fluids until 10:30 p.m. of the night before and was given $500 \mathrm{ml}$ of water to drink at 7:30 a.m. on the day of the study. Solutions containing 5 per cent dextrose or 4 per cent fructose in water were infused at 15 to $16 \mathrm{ml}$ per minute beginning at 8:00 a.m. Urine was collected as frequently as the subject could void until urine flow was constant; isotonic ( 5 per cent) mannitol or 0.7 per cent saline was then substituted for the hexose. These studies are discussed under Results V.

Some studies of acute water diuresis were repeated under identical conditions except that Pitressin ${ }^{1}$ (vasopressin aqueous) $10 \mathrm{mU}$ or 100 to $200 \mu \mathrm{U}$ per $\mathrm{kg}$ per

1 Parke-Davis Lot 184. 
TABLE I

Effect of oral water loads (20 $\mathrm{ml}$ per $\mathrm{kg}$ ) on urine and serum in normal subjects

\begin{tabular}{|c|c|c|c|c|c|c|c|c|c|}
\hline \multirow[b]{3}{*}{ Subject } & \multicolumn{3}{|c|}{$4 \mathrm{hr}$ urine* } & \multicolumn{6}{|c|}{ Serum } \\
\hline & \multirow[b]{2}{*}{$\%$ of load $\dagger$} & \multirow{2}{*}{$\begin{array}{c}\mathrm{F}_{\mathrm{H} 2 \mathrm{O}} \\
\text { as \% of } \\
\text { load }\end{array}$} & \multirow[b]{2}{*}{$\begin{array}{c}\text { Minimum } \\
\text { osmolality }\end{array}$} & \multicolumn{3}{|c|}{ Osmolality } & \multicolumn{3}{|c|}{ Sodium } \\
\hline & & & & Start & $\begin{array}{l}\text { After } \\
\text { load\& }\end{array}$ & $\begin{array}{l}\text { End of } \\
\text { study }\end{array}$ & Start & $\begin{array}{l}\text { After } \\
\text { load\& }\end{array}$ & $\begin{array}{l}\text { End of } \\
\text { study }\end{array}$ \\
\hline & & & $m O s m / k g \|$ & \multicolumn{3}{|c|}{$m O s m / k g$} & \multicolumn{3}{|c|}{$m E q / L$} \\
\hline G. C., 20 yrs, $\sigma^{\top}$ & $\begin{array}{l}111 \\
100\end{array}$ & $\begin{array}{l}59 \\
54\end{array}$ & $\begin{array}{r}83 \\
101\end{array}$ & $\begin{array}{l}286 \\
295\end{array}$ & $\begin{array}{l}282 \\
285\end{array}$ & $\begin{array}{l}284 \\
293\end{array}$ & $\begin{array}{l}144 \\
146\end{array}$ & $\begin{array}{l}141 \\
139\end{array}$ & $\begin{array}{l}142 \\
145\end{array}$ \\
\hline T. T., 21 yrs, ơ & $\begin{array}{l}94 \\
84\end{array}$ & $\begin{array}{l}52 \\
50\end{array}$ & $\begin{array}{l}69 \\
55\end{array}$ & $\begin{array}{l}288 \\
288\end{array}$ & $\begin{array}{l}282 \\
283\end{array}$ & $\begin{array}{l}286 \\
286\end{array}$ & $\begin{array}{l}140 \\
142\end{array}$ & $\begin{array}{l}137 \\
138\end{array}$ & $\begin{array}{l}142 \\
140\end{array}$ \\
\hline E. S., 20 yrs, $\%$ & 99 & 69 & 49 & 297 & 282 & 288 & 141 & 138 & \\
\hline E. W., 16 yrs, ? & 96 & 59 & 59 & 288 & 283 & & 143 & 140 & 142 \\
\hline 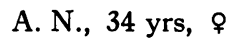 & 108 & 97 & 49 & 289 & 285 & 287 & 135 & & 134 \\
\hline Average & 99 & 63 & 66 & 290 & 283 & 287 & 142 & 139 & 141 \\
\hline
\end{tabular}

* Comprises all voidings during the 4 hrs from the end of ingestion of the "load."

$\dagger$ Ratio of $4 \mathrm{hr}$ volume to total volume ingested $\times 100$.

$\ddagger$ Ratio of total free water excreted in 4 hrs to total volume ingested $\times 100$.

$\$ 2 \mathrm{hrs}$ after start of ingestion.

|| Osmolality of most dilute specimen obtained.

hour, was added to the infusate. These studies are discussed under Results VIII.

Serum and urine osmolality was estimated from freezing point depression (6), readings for unknowns being interpolated between standards. The concentrations of sodium chloride used in standard solutions were corrected for true osmolality (7). Total solute is thus reported as milliosmoles per kilogram of water.

Free water clearance $\left(\mathrm{C}_{\mathrm{F}_{2} \mathrm{O}}\right)$ is calculated as the dif- ference between urinary flow $(\mathrm{V})$ and osmolal clearance: $\mathrm{C}_{\mathrm{F}_{\mathrm{H} 2} \mathrm{O}}=\mathrm{V}-\left(\mathrm{U}_{\mathrm{osm}} \mathrm{V} / \mathrm{S}_{\text {osm }}\right)$, where $\mathrm{V}=$ urinary flow $(\mathrm{ml}$ per $\min ) ; U_{o s m}=$ osmolal concentration of urine, and $\mathrm{S}_{\mathrm{s} m \mathrm{~m}}=$ osmolal concentration of serum (8).

Serum and urine sodium and potassium were measured by internal standard flame photometry. The clearance of alkali stable inulin was measured by the method of Walser, Davidson and Orloff (9) and of creatinine by the method of Bonsnes and Taussky (10).

TABLE II

Effect of oral water loads $(20 \mathrm{ml}$ per $\mathrm{kg})$ on urine and serum in patients with cirrhosis

\begin{tabular}{|c|c|c|c|c|c|c|c|c|c|}
\hline \multirow[b]{3}{*}{ Subject } & \multicolumn{3}{|c|}{$4 \mathrm{hr}$ urine* } & \multicolumn{6}{|c|}{ Serum } \\
\hline & \multirow[b]{2}{*}{$\%$ of loadt } & \multirow{2}{*}{$\begin{array}{c}F_{\text {Bgot }} \\
\text { as \% of } \\
\text { load }\end{array}$} & \multirow[b]{2}{*}{$\begin{array}{l}\text { Minimum } \\
\text { osmolality }\end{array}$} & \multicolumn{3}{|c|}{ Osmolality } & \multicolumn{3}{|c|}{ Sodium } \\
\hline & & & & Start & $\begin{array}{l}\text { After } \\
\text { load \& }\end{array}$ & $\begin{array}{c}\text { End of } \\
\text { study }\end{array}$ & Start & $\begin{array}{l}\text { After } \\
\text { load } \delta\end{array}$ & $\begin{array}{l}\text { End of } \\
\text { słudy }\end{array}$ \\
\hline & & & $m O s m / k g \|$ & \multicolumn{3}{|c|}{$m O s m / k g$} & \multicolumn{3}{|c|}{$m E q / L$} \\
\hline H. F., 47 yrs, ه & $\begin{array}{l}52 \pi \\
48 \\
36 \\
34\end{array}$ & $\begin{array}{r}24 \\
24 \\
8 \\
8\end{array}$ & $\begin{array}{l}113 \\
111 \\
180 \\
194\end{array}$ & $\begin{array}{l}290 \\
284 \\
277 \\
277\end{array}$ & $\begin{array}{l}277 \\
276 \\
268 \\
269\end{array}$ & $\begin{array}{l}282 \\
281 \\
272 \\
274\end{array}$ & $\begin{array}{l}144 \\
141 \\
133 \\
130\end{array}$ & $\begin{array}{l}135 \\
135 \\
128 \\
124\end{array}$ & $\begin{array}{l}139 \\
138 \\
129 \\
125\end{array}$ \\
\hline W. S., 34 yrs, ه & $\begin{array}{l}28 \\
45\end{array}$ & $\begin{array}{l}17 \\
30\end{array}$ & $\begin{array}{l}74 \\
55\end{array}$ & $\begin{array}{l}275 \\
284\end{array}$ & $\begin{array}{l}270 \\
275\end{array}$ & $\begin{array}{l}275 \\
278\end{array}$ & $\begin{array}{l}136 \\
138\end{array}$ & $\begin{array}{l}131 \\
135\end{array}$ & $\begin{array}{l}133 \\
137\end{array}$ \\
\hline N. K., 68 yrs, ơ & 23 & 0.2 & 239 & 259 & 250 & & & & \\
\hline Average & 38 & 16 & 138 & 278 & 269 & 277 & 137 & 131 & 134 \\
\hline
\end{tabular}

* Comprises all voidings during the $4 \mathrm{hrs}$ from the end of ingestion of the "load."

$\dagger$ Ratio of $4 \mathrm{hr}$ volume to total volume ingested $\times 100$.

$\$$ Ratio of total free water excreted in $4 \mathrm{hrs}$ to total volume ingested $\times 100$.

$2 \mathrm{hrs}$ after start of ingestion.

Osmolality of most dilute specimen obtained.

$30 \mathrm{ml}$ per $\mathrm{kg}$ load. 
TABLE III

Effect of intravenous water* loads $(20 \mathrm{ml}$ per $\mathrm{kg}$ ) on urine, and serum: comparison of normal and cirrhotic subjects

\begin{tabular}{|c|c|c|c|c|c|c|c|c|c|c|}
\hline \multirow[b]{3}{*}{ Subject } & \multicolumn{3}{|c|}{$4 \mathrm{hr}$ urinet } & \multicolumn{6}{|c|}{ Serum } & \multirow[b]{3}{*}{$\underset{\left(\mathrm{C}_{\mathrm{ar}}\right)}{\mathrm{GFR}}$} \\
\hline & \multirow[b]{2}{*}{$\begin{array}{c}\% \text { of } \\
\text { loadf }\end{array}$} & \multirow{2}{*}{$\begin{array}{l}\mathrm{F}_{\mathrm{H} 2 \mathrm{O}} \\
\text { as } \\
\% \text { of } \\
\text { load }\end{array}$} & \multirow{2}{*}{$\begin{array}{l}\text { Mini- } \\
\text { mum } \\
\text { osmo- } \\
\text { lality }\end{array}$} & \multicolumn{3}{|c|}{ Osmolality } & \multicolumn{3}{|c|}{ Sodium } & \\
\hline & & & & Start & $\begin{array}{c}\text { After } \\
\text { loadll }\end{array}$ & $\begin{array}{l}\text { End of } \\
\text { study }\end{array}$ & Start & $\begin{array}{l}\text { After } \\
\text { load\|l }\end{array}$ & $\begin{array}{c}\text { End of } \\
\text { study }\end{array}$ & \\
\hline & & & $m 0 s m / k g \pi$ & & \multicolumn{2}{|c|}{$\mathrm{mOsm} / \mathrm{kg}$} & \multicolumn{3}{|c|}{$m E q / L$} & $m l / m i n$ \\
\hline 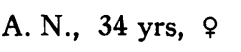 & 109 & 83 & 35 & 288 & 285 & 287 & 140 & 137 & 142 & \\
\hline D. R., 20 yrs, $\%$ & 86 & 38 & 86 & 290 & 286 & 284 & 142 & 138 & 139 & 98 \\
\hline S. Y., 20 yrs, $\$$ & $\begin{array}{l}88 \\
80\end{array}$ & $\begin{array}{l}53 \\
61\end{array}$ & $\begin{array}{l}54 \\
46\end{array}$ & $\begin{array}{l}283 \\
290\end{array}$ & $\begin{array}{l}278 \\
283\end{array}$ & $\begin{array}{l}281 \\
283\end{array}$ & $\begin{array}{l}137 \\
141\end{array}$ & $\begin{array}{l}134 \\
138\end{array}$ & $\begin{array}{l}135 \\
139\end{array}$ & 79 \\
\hline Average & 91 & 59 & 55 & 288 & 283 & 284 & 140 & 137 & 139 & \\
\hline \multicolumn{11}{|c|}{ Cirrhotics } \\
\hline H. F., 47 yrs, $\sigma^{7}$ & $\begin{array}{l}28 \\
21 \\
23\end{array}$ & $\begin{array}{r}13 \\
4 \\
3\end{array}$ & $\begin{array}{r}97 \\
136 \\
151\end{array}$ & $\begin{array}{l}289 \\
260 \\
280\end{array}$ & $\begin{array}{l}277 \\
250 \\
267\end{array}$ & $\begin{array}{l}276 \\
254 \\
271\end{array}$ & $\begin{array}{l}136 \\
127 \\
133\end{array}$ & $\begin{array}{l}135 \\
125 \\
133\end{array}$ & $\begin{array}{l}137 \\
126 \\
133\end{array}$ & $\begin{array}{l}66 \\
62\end{array}$ \\
\hline M. M., 45 yrs, & 36 & 21 & 68 & 278 & 275 & 269 & 140 & 134 & 136 & 54 \\
\hline Т. Т., $47 \mathrm{yrs}, \sigma^{7}$ & 50 & 33 & 69 & 288 & 285 & 283 & 144 & 142 & 142 & 90 \\
\hline M. P., 52 yrs, $\sigma^{7}$ & $\begin{array}{l}42 \\
21^{* *}\end{array}$ & $\begin{array}{c}15 \\
1.3\end{array}$ & $\begin{array}{l}104 \\
188\end{array}$ & $\begin{array}{l}289 \\
286\end{array}$ & $\begin{array}{l}283 \\
274\end{array}$ & $\begin{array}{l}281 \\
274\end{array}$ & $\begin{array}{l}141 \\
140\end{array}$ & 131 & $\begin{array}{l}141 \\
135\end{array}$ & $\begin{array}{l}71 \\
66\end{array}$ \\
\hline Average & 32 & 13 & 116 & 281 & 273 & 273 & 137 & 133 & 136 & \\
\hline
\end{tabular}

* Given as $5 \%$ dextrose or $4 \%$ fructose.

+Comprises all voidings during the 4 hrs from midpoint of infusion of "load."

\pm Ratio of $4 \mathrm{hr}$ volume to total volume infused $\times 100$.

Ratio of total free water excreted in $4 \mathrm{hrs}$ to total volume infused $\times 100$.

15 minutes after end of infusion.

of Osmolality of most dilute specimen obtained.

** Study done 2 days after paracentesis.

\section{RESULTS}

I. Response to oral water loading. In Tables I and II are compared the responses to oral water loads of normal subjects and patients with hepatic cirrhosis. As compared with the normal subjects, the patients excreted $a$ ) an average of less than half as much urine, $b$ ) one-quarter of the amount of free water, and $c$ ) urine of minimum osmolality twice as great. The serum osmolality $d$ ) fell to a comparable degree in the two groups, and the serum sodium concentration, $e$ ) fell slightly more in the patients. The initial serum osmolality was significantly lower $(p<0.02)$ in the patients, and the sodium concentration was suggestively lower $(p<0.10)$. Despite the limitation in volume of flow, urine became hypotonic to plasma in all patients.

II. Response to intravenous water loading. In Table III are compared the responses of normal subjects and of patients with hepatic cirrhosis to intravenous water loads ( 5 per cent dextrose or 4 per cent fructose solutions). The results are essentially the same as with oral water loads.

III. Response to intravenous loading with unreabsorbable solute. In Figure 1 are compared the responses of Patient H.F. to three isotonic water loads of equal volume $(20 \mathrm{ml}$ per $\mathrm{kg})$. In $\mathrm{I}$, all the water given is "free" water ( 5 per cent dextrose solution); in II half is given as a 5 per cent mannitol solution; and in III, three-quarters is given as a 5 per cent mannitol solution. The excretion of free water varies inversely with the volume of free water given.

Table IV shows the responses of the normal subjects and patients shown in Table III to intravenous loading with the same volumes $(20 \mathrm{ml}$ per $\mathrm{kg}$ ) of water containing mannitol. For the normal subjects the excretion of free water was lower when the load contained unreabsorbable solute. 


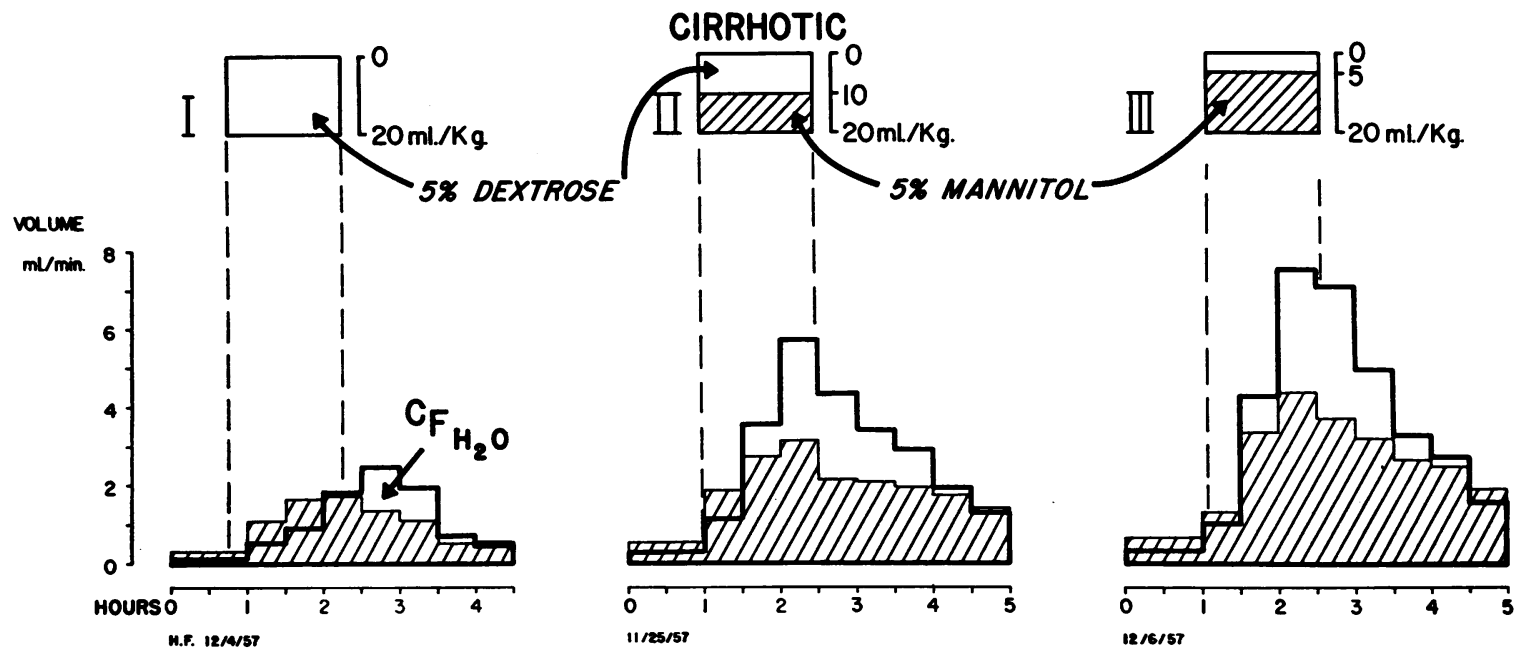

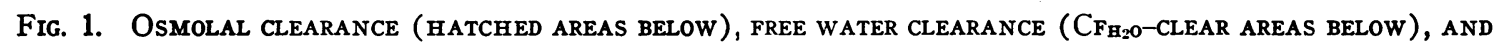
URINE VOLUME (HEAVY LINES) IN A PATIENT WITH CIRRHOSIS INFUSED WITH EQUAL ISOTONIC LOADS: EFFECT OF SUBSTITUTION OF MANNITOL (HATChed AREAS ABOVE) FOR DEXTROSE (CleAR AREAS ABove). Note that more free water is excreted from I to III, despite decreasing amounts of free water infused.

TABLE IV

Effect of intravenous loads (20 ml per $\mathrm{kg}$ ) containing unreabsorbable solute (mannitol) on urine and serum: comparison of normal and cirrhotic subjects

\begin{tabular}{|c|c|c|c|c|c|c|c|c|c|c|c|c|}
\hline \multirow[b]{3}{*}{ Subject } & \multicolumn{4}{|c|}{$4 \mathrm{hr}$ urine* } & \multicolumn{6}{|c|}{ Serum } & \multirow[b]{3}{*}{$\begin{array}{l}\text { GFR } \\
\text { (C) }\end{array}$} & \multirow{3}{*}{$\begin{array}{l}\text { Ratio } \\
5 \% \text { dextrose } \\
5 \% \text { mannito }\end{array}$} \\
\hline & \multirow[b]{2}{*}{$\begin{array}{l}\% \text { of } \\
\text { load† }\end{array}$} & \multirow{2}{*}{$\begin{array}{c}\mathrm{F}_{\mathrm{H} 2 \mathrm{O}} \neq \\
\text { as } \\
\% \text { of } \\
\text { load }\end{array}$} & \multirow{2}{*}{$\begin{array}{c}\text { \% } \mathrm{F}_{\mathrm{H} 2 \mathrm{O}} \\
\text { given } \\
\text { excreted } \\
\text { as } \mathrm{F}_{\mathrm{H}_{2} \mathrm{O}}\end{array}$} & \multirow{2}{*}{$\begin{array}{l}\text { Mini- } \\
\text { mum } \\
\text { osmo- } \\
\text { lality }\end{array}$} & \multicolumn{3}{|c|}{ Osmolality } & \multicolumn{3}{|c|}{ Sodium } & & \\
\hline & & & & & Start & $\begin{array}{l}\text { After } \\
\text { load\| }\end{array}$ & $\begin{array}{l}\text { End of } \\
\text { study }\end{array}$ & Start & $\begin{array}{l}\text { After } \\
\text { load\| }\end{array}$ & $\begin{array}{l}\text { End of } \\
\text { study }\end{array}$ & & \\
\hline & & & & $m O s m / k g ף$ & \multicolumn{3}{|c|}{$\begin{array}{l}m O s m / k g \\
\text { Normals }\end{array}$} & \multicolumn{3}{|c|}{$m E q / L$} & & \\
\hline A. $\mathrm{N}$. & 101 & 56 & 111 & 85 & 282 & 281 & & 140 & 128 & & & $1 / 1$ \\
\hline D. R. & 102 & 34 & 67 & 112 & 286 & 293 & 287 & 143 & 138 & 140 & & $1 / 1$ \\
\hline S. Y. & $\begin{array}{r}95 \\
83 \\
105\end{array}$ & $\begin{array}{l}16 \\
19 \\
14\end{array}$ & $\begin{array}{l}48 \\
57 \\
88\end{array}$ & $\begin{array}{l}186 \\
138 \\
202\end{array}$ & $\begin{array}{l}288 \\
285 \\
285\end{array}$ & $\begin{array}{l}284 \\
281 \\
289\end{array}$ & $\begin{array}{l}283 \\
283 \\
283\end{array}$ & $\begin{array}{l}137 \\
144 \\
137\end{array}$ & $\begin{array}{l}131 \\
134 \\
132\end{array}$ & $\begin{array}{l}134 \\
139 \\
133\end{array}$ & $\begin{array}{l}87 \\
90\end{array}$ & $\begin{array}{l}1 / 2 \\
1 / 2 \\
1 / 3\end{array}$ \\
\hline Average & 97 & 28 & 74 & 145 & 285 & 286 & 284 & 140 & 133 & 137 & & \\
\hline \multicolumn{13}{|c|}{ Cirrhotics } \\
\hline H. F. & $\begin{array}{l}60 \\
65\end{array}$ & $\begin{array}{l}21 \\
21\end{array}$ & $\begin{array}{l}42 \\
83\end{array}$ & $\begin{array}{l}138 \\
141\end{array}$ & $\begin{array}{l}276 \\
273\end{array}$ & $\begin{array}{l}273 \\
267\end{array}$ & $\begin{array}{l}266 \\
275\end{array}$ & $\begin{array}{l}129 \\
131\end{array}$ & $\begin{array}{l}123 \\
128\end{array}$ & $\begin{array}{l}125 \\
131\end{array}$ & $\begin{array}{l}48 \\
49\end{array}$ & $\begin{array}{l}1 / 1 \\
1 / 3\end{array}$ \\
\hline M. M. & 75 & 32 & 63 & 129 & 287 & 285 & 283 & 145 & & 140 & 65 & $1 / 1$ \\
\hline T. T. & 121 & 41 & 164 & 161 & 290 & 291 & 300 & 137 & 132 & 135 & 147 & $1 / 3$ \\
\hline M. P. & $\begin{array}{l}71 \\
61^{* *}\end{array}$ & $\begin{array}{l}27 \\
18\end{array}$ & $\begin{array}{l}54 \\
36\end{array}$ & $\begin{array}{r}95 \\
124\end{array}$ & $\begin{array}{l}286 \\
279\end{array}$ & $\begin{array}{l}286 \\
278\end{array}$ & $\begin{array}{l}286 \\
278\end{array}$ & $\begin{array}{l}142 \\
140\end{array}$ & $\begin{array}{l}137 \\
127\end{array}$ & $\begin{array}{l}140 \\
134\end{array}$ & $\begin{array}{l}86 \\
79\end{array}$ & $\begin{array}{l}1 / 1 \\
1 / 1\end{array}$ \\
\hline Average & 76 & 27 & 74 & 131 & 282 & 280 & 281 & 137 & 129 & 134 & & \\
\hline
\end{tabular}

* Comprises all voidings during the 4 hrs from midpoint of infusion of "load."

$\dagger$ Ratio of $4 \mathrm{hr}$ volume to total volume infused $\times 100$.

Ratio of total free water excreted in $4 \mathrm{hrs}$ to total volume infused $\times 100$.

Ratio of total free water excreted in $4 \mathrm{hrs}$ to total volume of free water infused $\times 100$.

15 minutes after end of infusion.

I Osmolality of most dilute specimen obtained.

** Study done 4 days after paracentesis. 
TABLE V

Effect of intravenous loads $(20 \mathrm{ml}$ per $\mathrm{kg})$ of $5 \%$ mannitol on urine and serum: comparison of normal and cirrhotic subjects

\begin{tabular}{|c|c|c|c|c|c|c|c|c|c|}
\hline \multirow[b]{3}{*}{ Subject } & \multicolumn{3}{|c|}{$4 \mathrm{hr}$ urine* } & \multicolumn{6}{|c|}{ Serum } \\
\hline & \multirow[b]{2}{*}{$\%$ of load $\dagger$} & \multirow{2}{*}{$\begin{array}{c}\mathrm{F}_{\mathrm{H}} \mathrm{O} \ddagger \\
\text { as \% of } \\
\text { load }\end{array}$} & \multirow[b]{2}{*}{$\begin{array}{l}\text { Minimum } \\
\text { osmolality }\end{array}$} & \multicolumn{3}{|c|}{ Osmolality } & \multicolumn{3}{|c|}{ Sodium } \\
\hline & & & & Start & $\begin{array}{l}\text { After } \\
\text { load\& }\end{array}$ & $\begin{array}{l}\text { End of } \\
\text { study }\end{array}$ & Start & $\begin{array}{l}\text { After } \\
\text { load } 8\end{array}$ & $\begin{array}{l}\text { End of } \\
\text { study }\end{array}$ \\
\hline \multirow{2}{*}{\multicolumn{10}{|c|}{ Normals }} \\
\hline & & & & & & & & & \\
\hline D. R. & 108 & 0 & 313 & 286 & 286 & 284 & 140 & 130 & 137 \\
\hline S. Y. & 65 & 0 & 353 & 287 & 279 & 283 & 141 & 130 & 135 \\
\hline \multicolumn{10}{|c|}{ Cirrhotics } \\
\hline T. T. & 130 & 29 & 186 & 286 & 283 & 290 & 140 & 133 & 137 \\
\hline M. M. & 86 & 14 & 207 & 288 & 293 & 288 & 142 & 138 & 139 \\
\hline M. P. & $\begin{array}{l}82 \\
64 \pi\end{array}$ & $\begin{array}{r}13 \\
5\end{array}$ & $\begin{array}{l}180 \\
214\end{array}$ & $\begin{array}{l}292 \\
306\end{array}$ & 286 & $\begin{array}{l}287 \\
266\end{array}$ & $\begin{array}{l}138 \\
134\end{array}$ & $\begin{array}{l}136 \\
127\end{array}$ & $\begin{array}{l}137 \\
144\end{array}$ \\
\hline H. F. & 55 & 6 & 216 & 276 & 280 & 283 & 141 & 134 & 134 \\
\hline J. B. & 62 & 1 & 265 & 277 & 279 & & & & \\
\hline Average & 80 & 11 & 211 & 288 & 284 & 283 & 139 & 134 & 138 \\
\hline \multicolumn{10}{|c|}{ Normal, sodium depleted } \\
\hline A. N. & 94 & 9 & 209 & 279 & 277 & & 140 & 124 & \\
\hline
\end{tabular}

* Comprises all voidings during the 4 hrs from midpoint of infusion of "load."

$\dagger$ Ratio of $4 \mathrm{hr}$ volume to total volume infused $\times 100$.

$\ddagger$ Ratio of total free water excreted in 4 hrs to total volume infused $\times 100$.

15 minutes after end of infusion.

II Osmolality of most dilute specimen obtained.

Study done 6 days after paracentesis.

TABLE VI

Effect of equal intravenous water* loads $(20 \mathrm{ml}$ per $\mathrm{kg}$ ) without and with unreabsorbable solute (mannitol) on urine and serum: comparison of a normal subject $(A . N$.) before and after sodium depletion

\begin{tabular}{|c|c|c|c|c|c|c|c|c|c|c|}
\hline \multicolumn{4}{|c|}{$4 \mathrm{hr}$ urinet } & \multicolumn{6}{|c|}{ Serum } & \multirow[b]{3}{*}{ Infusate } \\
\hline \multirow[b]{2}{*}{$\begin{array}{l}\% \text { of } \\
\text { load }\end{array}$} & \multirow{2}{*}{$\begin{array}{l}\mathrm{F}_{\mathrm{Hz}} \mathrm{O} \\
\text { as } \\
\% \text { of } \\
\text { load }\end{array}$} & \multirow{2}{*}{$\begin{array}{c}\% \mathrm{FH}_{\mathrm{H}_{\mathrm{O}} \mathrm{O}} \\
\text { given } \\
\text { excreted } \\
\text { as } \mathrm{F}_{\mathrm{H}_{2} \mathrm{O}}\end{array}$} & \multirow{2}{*}{$\begin{array}{l}\text { Mini- } \\
\text { mum } \\
\text { osmo- } \\
\text { lality }\end{array}$} & \multicolumn{3}{|c|}{ Osmolality } & \multicolumn{3}{|c|}{ Sodium } & \\
\hline & & & & Start & $\begin{array}{l}\text { After } \\
\text { load }\end{array}$ & End & Start & $\begin{array}{l}\text { After } \\
\text { load I }\end{array}$ & End & \\
\hline & & & $m O s m / k g * *$ & \multicolumn{3}{|c|}{$\begin{array}{l}\quad m O s m / k g \\
\text { Before sodium depletion }\end{array}$} & \multicolumn{3}{|c|}{$m E q / L$} & $20 \mathrm{ml} / \mathrm{kg}$ \\
\hline 109 & 83 & 83 & 35 & 288 & 285 & 287 & 140 & 137 & 142 & $5 \%$ Dextrose \\
\hline 101 & 56 & 111 & 85 & 282 & 281 & & 140 & 128 & & $\frac{5 \% \text { Dextrose: } 1}{5 \% \text { Mannitol: } 1}$ \\
\hline \multicolumn{11}{|c|}{ After sodium depletion } \\
\hline 34 & 9 & 9 & 96 & 281 & 270 & & 135 & 128 & & $5 \%$ Dextrose \\
\hline 108 & 38 & 76 & 147 & 275 & 270 & 272 & 134 & 130 & 139 & $\frac{5 \% \text { Dextrose: } 1}{5 \% \text { Mannitol: } 1}$ \\
\hline
\end{tabular}

* Given as $5 \%$ dextrose.

† Comprises all voidings during the 4 hrs from midpoint of infusion of "load."

$\$$ Ratio of $4 \mathrm{hr}$ volume to total volume infused $\times 100$.

Ratio of total free water excreted in 4 hrs to total volume infused $\times 100$.

Ratio of total free water excreted in 4 hrs to total volume of free water infused $\times 100$.

15 minutes after end of infusion.

** Osmolality of most dilute specimen obtained. 
NORMAL

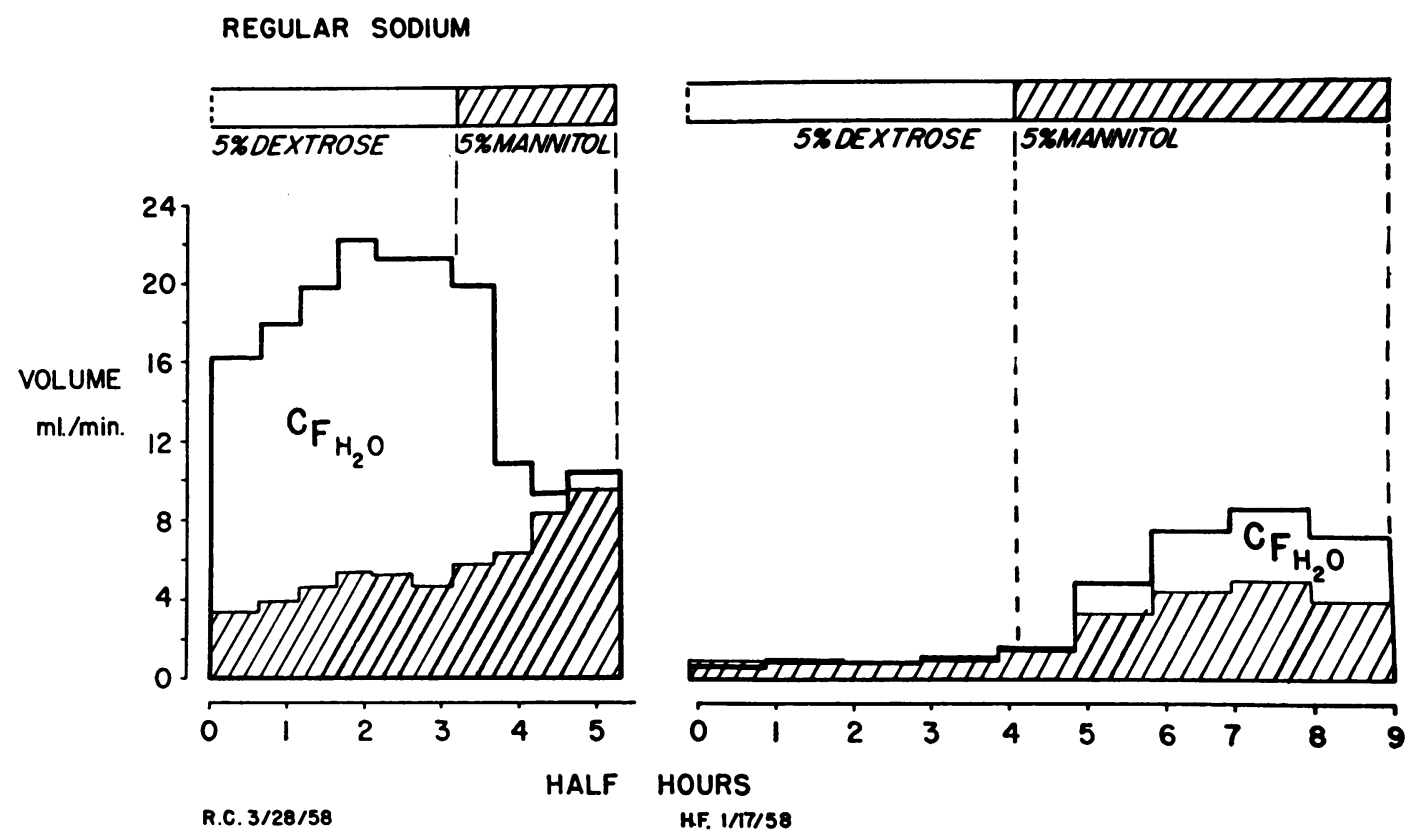

Fig. 2. Osmolal clearance (hatched areas below), free water clearance (CF h H -Clear areas BELOW) AND URINE VOLUME (HEAVY LINES) IN A NORMAL SUBJECT AND IN A PATIENT WITH CIRRHOSIS : EFFeCt of SUbStitution of MANNitol (hatched AReas above) FOR Dextrose (Clear areas above). Note the increase in free water in the patient as contrasted with the fall in free water in the normal subject when unreabsorbable solute is given.

In contrast the patients showed greater free water excretions with loads containing unreabsorbable solute and thus less free water.

Table V compares the response of three normal subjects (one of whom was depleted of sodium) and of five patients with cirrhosis to the same volume $(20 \mathrm{ml}$ per $\mathrm{kg})$ of a 5 per cent solution of mannitol. In the patients and in the salt-depleted normal subject, but not in the normal subjects on average sodium intake, free water was excreted in response to the load of wholly "obligated" water.

$I V$. Response of a sodium-depleted normal subject to intravenous loading. Table VI compares the response of a normal subject to equal intravenous loads $(20 \mathrm{ml}$ per $\mathrm{kg}$ of a 5 per cent dextrose solution with $20 \mathrm{ml}$ per $\mathrm{kg}$ of 2.5 per cent mannitol in a 2.5 per cent dextrose solution) both before and after sodium depletion. Whereas the substitution of unreabsorbable solute had lowered the amount of free water excreted on ad libitum sodium intake, it raised it after sodium depletion. (Compare the fall in free water from 83 to 56 per cent of the load on ad libitum sodium, with the rise from 9 to 38 per cent after sodium depletion.)

$V$. Response to intravenous loading with unreabsorbable solute during sustained water diuresis. Figure 2 compares the effect of substituting infusions of 5 per cent solutions of mannitol for 5 per cent dextrose solutions during sustained diuresis in a normal subject and in a patient with cirrhosis. Table VII shows the results of this procedure in four patients with cirrhosis and in two normal subjects before and after sodium depletion. The substitution of unreabsorbable solute lowered free water clearance in the normal subjects before sodium depletion and raised it after sodium depletion; it uniformly raised it in the patients with cirrhosis. Table VII shows also the glomerular filtration rates (GFR as inulin or creatinine clearance) during these studies. These rates tended to fall as urine volume rose with mannitol in the patients with cirrhosis. (The apparent falls observed in the normal subjects before sodium depletion may be largely artifacts, resulting from the precipitous falls in urine volume.) 


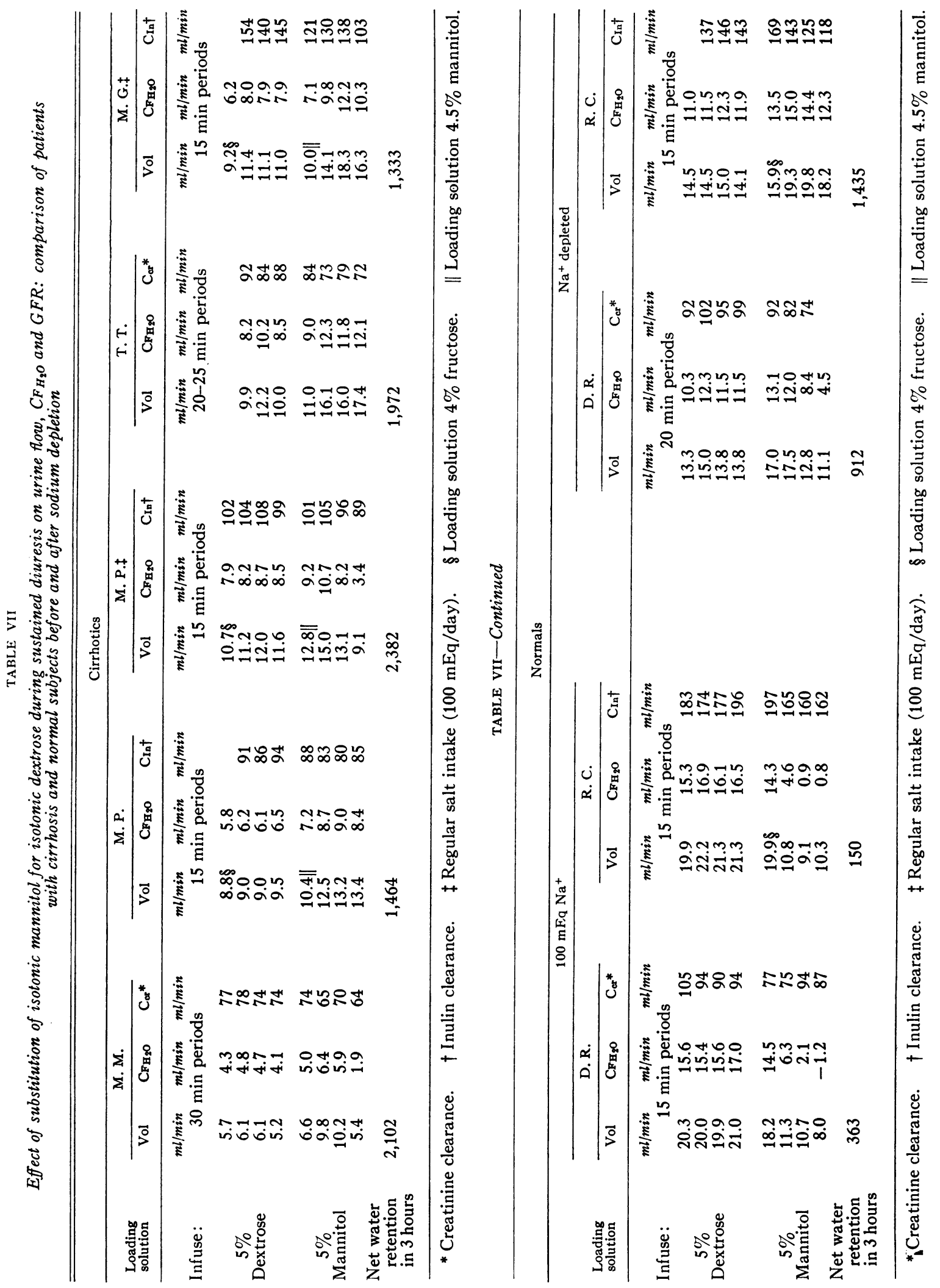


TABLE VIII

Effect of substitution of isotonic saline for isotonic dextrose during sustained diuresis on urine flow, CF $\mathrm{H}_{2} \mathrm{O}$ and $G F R$ : comparison of patients with cirrhosis and a normal subject before and after sodium depletion

\begin{tabular}{|c|c|c|c|c|c|c|c|c|c|c|c|}
\hline \multicolumn{6}{|c|}{ Cirrhotics } & \multicolumn{6}{|c|}{ Normal } \\
\hline \multirow{3}{*}{$\begin{array}{l}\text { Loading } \\
\text { solution } \\
\text { infused }\end{array}$} & \multirow{2}{*}{\multicolumn{2}{|c|}{ M. P. }} & \multirow{2}{*}{\multicolumn{3}{|c|}{ M. G. }} & \multicolumn{3}{|c|}{ High sodium } & \multicolumn{3}{|c|}{ Sodium depleted } \\
\hline & & & & & & & R. C. & & & R. C. & \\
\hline & Vol & $\mathrm{CF}_{\mathrm{H}_{2} \mathrm{O}}$ & Vol & $\mathrm{C}_{\mathrm{F}_{20} \mathrm{O}}$ & $\mathrm{C}_{\mathrm{In}^{*}}$ & Vol & $\mathrm{CF}_{\mathrm{H}_{2} \mathrm{O}}$ & $\mathrm{C}_{\mathrm{In}} *$ & Vol & $\mathrm{C}_{\mathrm{FH} P \mathrm{O}}$ & $\mathrm{C}_{\mathrm{In}} *$ \\
\hline & $m l / m i n$ & $m l / m i n$ & $\operatorname{ml} / \min$ & $m l / m i n$ & $\begin{array}{l}\text { ml } / \min \\
15 \text { minute periods }\end{array}$ & $\operatorname{ml} / \min$ & $\operatorname{ml} / \min$ & $m l / m i n$ & $m b / m i n$ & $\mathrm{ml} / \mathrm{min}$ & $m l / m i n$ \\
\hline $\begin{array}{l}4 \% \\
\text { Fructose }\end{array}$ & $\begin{array}{l}9.1 \\
9.3 \\
9.3\end{array}$ & $\begin{array}{l}6.2 \\
6.6 \\
6.5\end{array}$ & $\begin{array}{r}10.5 \\
9.9 \\
10.7\end{array}$ & $\begin{array}{l}7.2 \\
6.8 \\
7.5\end{array}$ & $\begin{array}{l}132 \\
126 \\
127\end{array}$ & $\begin{array}{l}23.3 \\
24.5 \\
25.2 \\
25.5\end{array}$ & $\begin{array}{l}17.1 \\
18.2 \\
19.0 \\
19.7\end{array}$ & $\begin{array}{l}165 \\
155 \\
150 \\
166\end{array}$ & $\begin{array}{l}7.9 \\
8.7 \\
8.3 \\
8.4\end{array}$ & $\begin{array}{l}4.8 \\
5.4 \\
5.3 \\
5.4\end{array}$ & $\begin{array}{l}122 \\
131 \\
124 \\
123\end{array}$ \\
\hline $\begin{array}{l}\text { Isotonic } \\
\text { saline }\end{array}$ & $\begin{array}{r}9.9 \\
10.3 \\
11.0 \\
10.2\end{array}$ & $\begin{array}{l}7.0 \\
8.6 \\
9.5 \\
8.8\end{array}$ & $\begin{array}{r}9.6 \\
12.4 \\
11.2\end{array}$ & $\begin{array}{l}6.9 \\
9.4 \\
8.7\end{array}$ & $\begin{array}{l}127 \\
124 \\
124\end{array}$ & $\begin{array}{r}24.1 \\
8.9 \\
6.5 \\
6.7\end{array}$ & $\begin{array}{r}17.7 \\
4.1 \\
1.3 \\
0.9\end{array}$ & $\begin{array}{l}155 \\
154 \\
147 \\
139\end{array}$ & $\begin{array}{r}8.8 \\
9.7 \\
9.7 \\
10.3 \\
9.9 \\
10.5 \\
10.3 \\
10.6\end{array}$ & $\begin{array}{l}6.0 \\
7.7 \\
7.8 \\
8.5 \\
8.4 \\
8.8 \\
8.5 \\
8.8\end{array}$ & $\begin{array}{l}134 \\
133 \\
126 \\
134 \\
133 \\
135 \\
129 \\
127\end{array}$ \\
\hline $\begin{array}{l}\text { Net water } \\
\text { retention } \\
\text { in } 3 \text { hours }\end{array}$ & 1,655 & & 1,585 & & & $-795 \dagger$ & & & 1,944 & & \\
\hline
\end{tabular}

* Inulin clearance.

† Subject had excreted a volume of urine $795 \mathrm{ml}$ greater than the sum of volumes of fluids drunk and infused.

$V I$. Response to intravenous loading with isotonic sodium chloride during sustained water diuresis. Table VIII shows the effect of substituting infusions of isotonic saline solutions for 5 per cent dextrose solutions during sustained diuresis in two patients with cirrhosis and in a normal subject before and after sodium depletion. The substitution of the sodium chloride raised free water clearance in the patients with cirrhosis and in the normal subject after sodium depletion, but lowered it in this subject before sodium depletion.

VII. Electrolyte excretion. Table IX shows the electrolyte excretion in all infusion studies. The total sodium $(\mathrm{Na})$ and potassium $(\mathrm{K})$ excretion is shown for the four-hour studies. For the studies of sustained diuresis, the table shows the total $\mathrm{Na}$ and $\mathrm{K}$ excretion for the one-hour period immediately before and immediately after the substitution of mannitol or saline in the infusion. It is apparent that in the studies of acute diuresis the unreabsorbable solute greatly increased potassium excretion in the patients with cirrhosis but not in the normal subjects. Whereas excreted $\mathrm{Na}$ rose with the mannitol in patients M.M., M.P. and T.T., it showed no rise in H.F., in whom the effect of mannitol on free water clearance was as great as in the others. Table IX shows also total solute excretion during sustained diuresis calculated as for $\mathrm{Na}$ and $\mathrm{K}$. Whereas mannitol produced increases in total solute excretion, sodium chloride, which induced as great a rise in free water excretion, led to decreases in total solute excretion.

VIII. Response to intravenous loads containing vasopressin. Figure 3 compares the responses to identical loads in the same individual without and with the addition of vasopressin, given at the rate of 100 to $200 \mu \mathrm{U}$ per $\mathrm{kg}$ per hour; this dose was estimated $(11,12)$ to be within the physiologic range of endogenous antidiuretic hormone production; the loads in the patient were those (vide supra) which had been shown to produce maximal free water clearance. All subjects cleared free water during the loading infusions without vasopressin. Vasopressin prevented the clearance of free water during the infusions. The "escape" from this vasopressin-induced antidiuresis was as rapid in the patients with cirrhosis as in the normal subjects.

\section{DISCUSSION}

These studies confirm numerous observations in the literature $(2,3,13)$ that total urine volume 

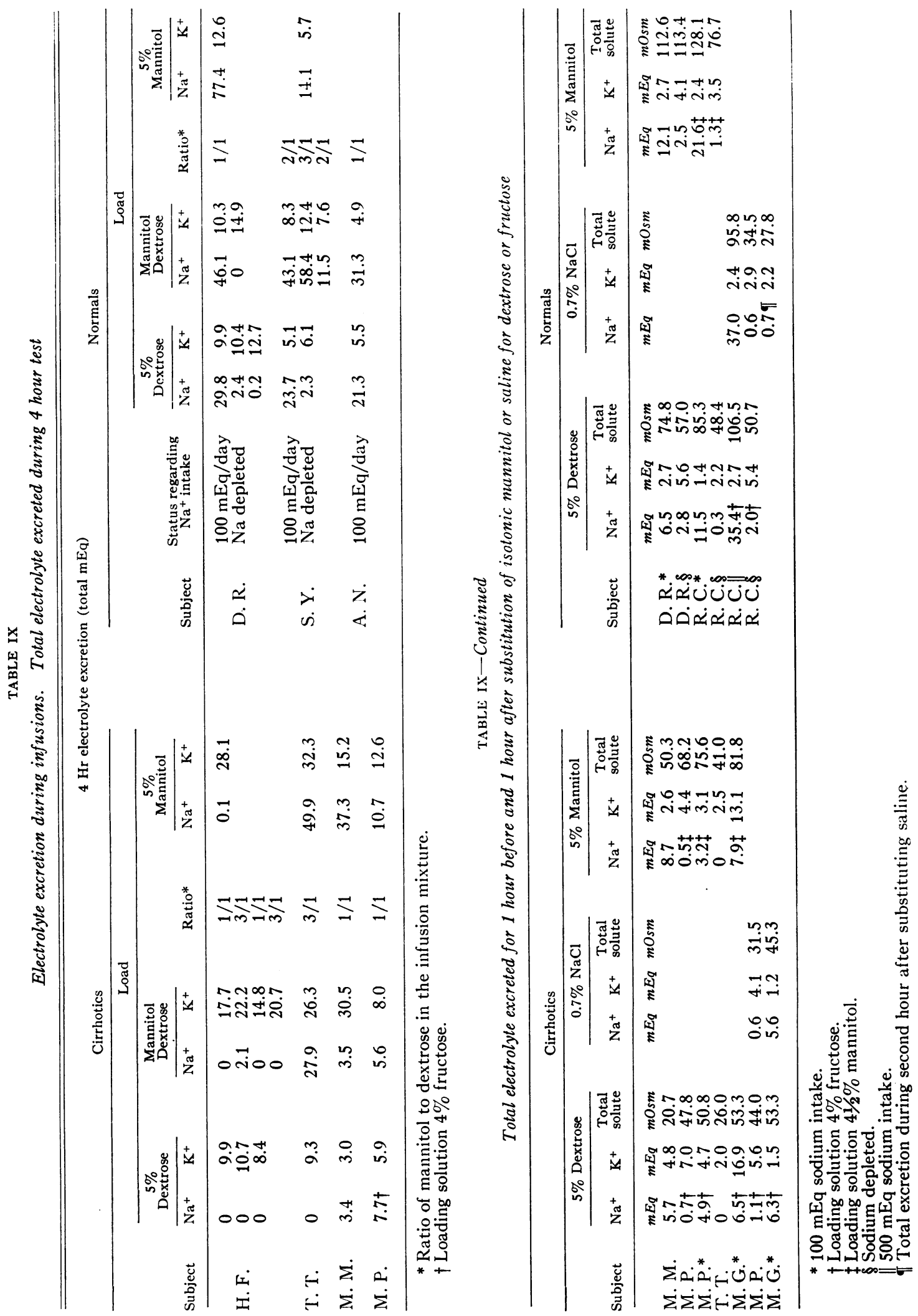


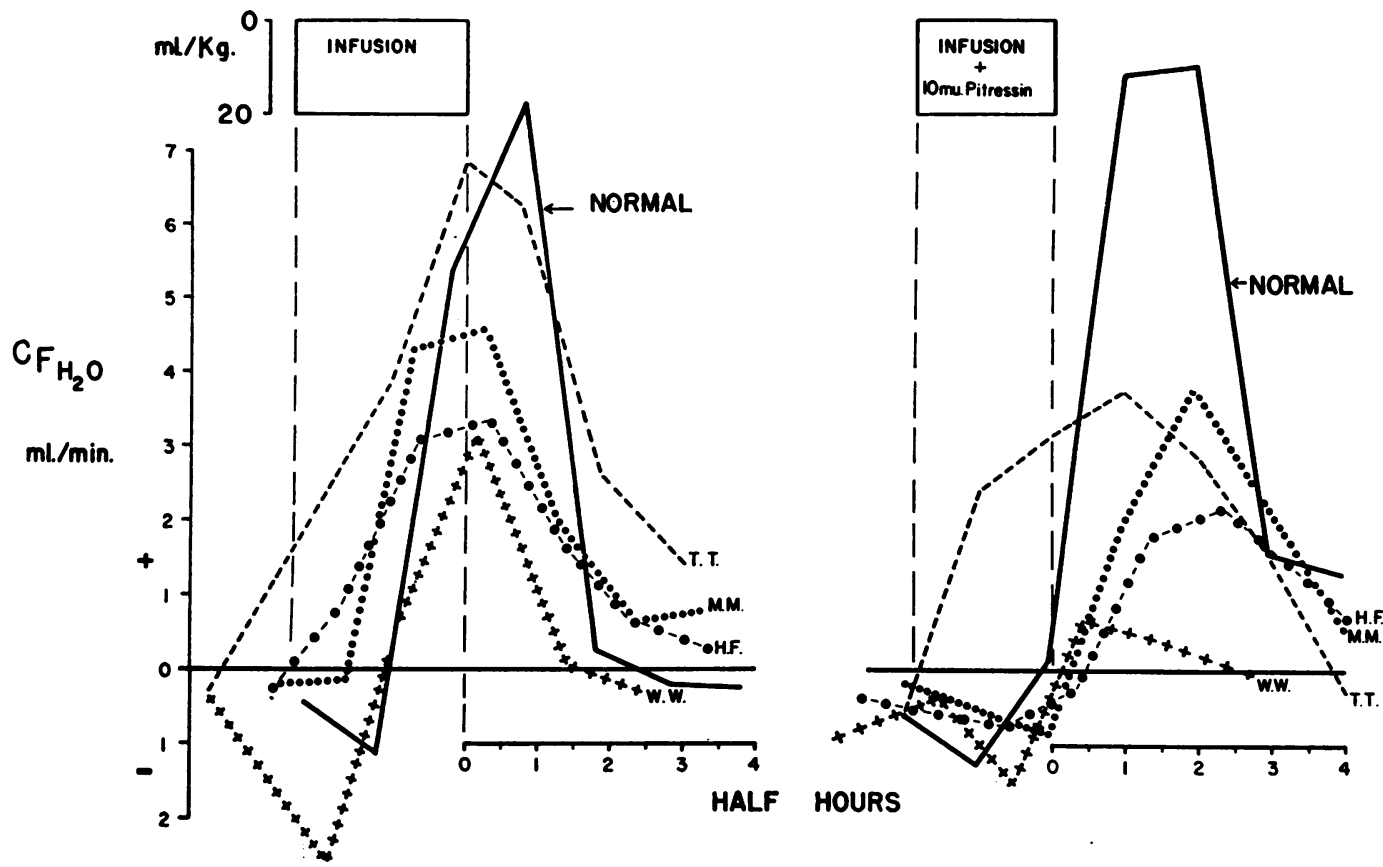

Fig. 3. Response of a NORMal SUbJect AND FOUR PATIENTS With CIRrhosis to IDENTICAL ISOTONIC INFUSIONS WITH AND Without $10 \mathrm{MU}$ OF PITRESSIN IN THE INFUSATE. Note that physiologic doses of Pitressin suppressed free water clearance during infusions but that escape occurred normally in the patients.

and free water excretion following water loads are limited in some patients with hepatic cirrhosis. The limitation is apparent both with oral and intravenous loading. (The glucose and fructose in the infusates was rapidly metabolized, blood levels returning to the normal range within an hour and a half.) It is unlikely that the impairment of diuresis is primarily the result of excessive production or persistence of action of ADH. Thus, all pa- tients excreted some free water during the tests (Tables II and III) and the onset of diuresis with mannitol-hexose infusates was as rapid in the patients as in the normal subjects (Figure 3 ). This "delay time" has been used as a measure of endogenous antidiuretic hormone (12). Physiologic doses of Pitressin prevented this clearance of free water. Furthermore, the "delay time" of "escape" from the administered Pitressin was nor-

TABLE $X$

Effect of five consecutive stages of sodium depletion on response to water loads* in a normal subject on metabolic regimen

\begin{tabular}{|c|c|c|c|c|c|c|c|c|c|}
\hline \multirow[b]{2}{*}{ Diet } & \multicolumn{3}{|c|}{ Urine } & \multicolumn{3}{|c|}{ Serum } & \multirow[b]{2}{*}{ C Inulin } & \multirow[b]{2}{*}{$\begin{array}{c}\mathrm{H}_{2} \mathrm{O}+\ddagger \\
\text { balance }\end{array}$} & \multirow[b]{2}{*}{$\mathrm{Wt} \delta$} \\
\hline & Volume & $\mathrm{C}_{\mathrm{FH} 2 \mathrm{O}} \dagger$ & $\begin{array}{l}\text { Osmo- } \\
\text { lality }\end{array}$ & $\begin{array}{l}\text { Osmo- } \\
\text { lality† }\end{array}$ & $\mathrm{Na}^{+}+$ & $\mathrm{Cl}+$ & & & \\
\hline & $\operatorname{ml} / \min$ & $m l / m i n$ & $m O s m / L$ & $m O s m / L$ & $m E q / L$ & $m E q / L$ & $m l / m i n$ & $m l$ & kg \\
\hline $\begin{array}{l}500 \mathrm{mEq} \mathrm{Na}^{+} \\
100 \mathrm{mEq} \mathrm{Na}^{+} \\
4 \mathrm{mEq} \mathrm{Na}\end{array}$ & $\begin{array}{l}25.5 \\
22.2\end{array}$ & $\begin{array}{l}19.7 \\
16.9\end{array}$ & $\begin{array}{l}66 \\
69\end{array}$ & $\begin{array}{l}287 \\
288\end{array}$ & $\begin{array}{l}138 \\
140\end{array}$ & 105 & $\begin{array}{l}157 \\
176\end{array}$ & $\begin{array}{l}795 \\
+\quad 323\end{array}$ & $\begin{array}{l}75.73 \\
73.59\end{array}$ \\
\hline $\begin{array}{l}\text { Thiomerin once } \\
\text { Thiomerin twice } \\
\text { Continue }\end{array}$ & $\begin{array}{r}15.0 \\
14.0 \\
8.4\end{array}$ & $\begin{array}{r}12.3 \\
10.0 \\
5.4\end{array}$ & $\begin{array}{l}50 \\
79 \\
99\end{array}$ & $\begin{array}{l}282 \\
275 \\
271\end{array}$ & $\begin{array}{l}132 \\
134 \\
132\end{array}$ & $\begin{array}{l}95 \\
94\end{array}$ & $\begin{array}{l}142 \\
124 \\
129\end{array}$ & $\begin{array}{l}+1,405 \\
+1,567 \\
+1,944\end{array}$ & $\begin{array}{l}70.65 \\
69.13 \\
69.07\end{array}$ \\
\hline
\end{tabular}

C. C., 24 yr old man.

* $500 \mathrm{ml}$ orally followed by $4 \%$ fructose intravenously at $16 \mathrm{ml}$ per min until maximum sustained volume flow was established.

$\dagger$ At maximum urine flow.

$\ddagger$ Volume of water given minus volume excreted in three hours

$\$$ At start of day. 
mal in the patients, suggesting a normal rate of inactivation. White, Rubin and Leiter (14) and Nelson and Welt (3) have reported apparently normal rates of inactivation of vasopressin in patients with cirrhosis. The findings do not support earlier conclusions $(2,15)$ which were not based upon measurements of free water clearance.

The urinary sodium excretion was consistently lower in the patients than in "normal" subjects (Table IX). This could result from excessive tubular resorption and from decreased filtered sodium load resulting both from decreased GFR and decreased serum sodium concentration. In T.T., M.G. and M.P., however, sodium excretion was low despite normal GFR and serum sodium concentration. In normal subjects, GFR need not fall, as the "defect" in $\mathrm{CF}_{\mathrm{H}_{2} \mathrm{O}}$ is induced by sodium depletion. See Table $X$, where a normal sodiumdepleted subject shows $\mathrm{CF}_{\mathrm{H}_{2} \mathrm{O}}$ of $10 \mathrm{ml}$ per minute with GFR of $124 \mathrm{ml}$ per minute (average of $4 \mathrm{C}_{\mathrm{IN}}$ periods : range 119.6 to $129.1 \mathrm{ml}$ per minute), and a $\mathrm{CF}_{\mathrm{H}_{2} \mathrm{O}}$ of $5.4 \mathrm{ml}$ per minute with a GFR of 129 $\mathrm{ml}$ per minute (average of $13 \mathrm{C}_{\mathrm{IN}}$ periods: range 121.5 to $134.9 \mathrm{ml}$ per minute) after further sodium depletion. The findings thus suggest that tubular sodium resorption was excessive. (The presence of large amounts of aldosterone in the urine of patients with cirrhosis and normal sodium-depleted subjects $(16,17)$ suggests that their capacity for tubular resorption of sodium is indeed above normal.) Despite this, the formation of free water, presumably a function of distal tubular sodium resorption (4), was limited. The findings thus suggest that whether or not the absolute amount of tubular sodium resorption was indeed excessive in these patients, it occurred largely in the proximal tubules as isosmotic fluid (18), leaving only small volumes of filtrate for distal free water generation. This interpretation allows an explanation of the production of free water in these patients with unreabsorbable solute; the solute would "deliver" proximal fluid to the appropriate distal site.

The data provide additional evidence in that the production of free water with mannitol is also accompanied by an increase in distal tubular ion exchange: the excretion of potassium, presumably a distal tubular function $(5,19)$ rose with mannitol in the patients but not in the normal subjects in whom mannitol did not produce an increase in free water clearance.

Birchard, Prout, Williams and Rosenbaum (20) reported that some patients with cirrhosis and moderate impairment of water diuresis after oral loading showed a significantly greater free water clearance when the load was given intravenously. Since the enhanced diuresis after intravenous loading was associated with an increase in sodium excretion, osmolar clearance, and $\mathrm{CF}_{\mathrm{H}_{2} \mathrm{O}}$, it was suggested that the "determinant" for the augmentation of diuresis after intravenous loading was the increase in excretion of sodium and other solutes. It appears likely that the hexoses in the infusates acted in a manner analogous to that of mannitol in the present studies; the potassium excretion was significantly higher with the intravenous loads (20). Infusion of dextrose tends to lower potassium excretion in normal subjects. Whereas the results of Birchard and associates can thus be explained as a result of delivery of proximal sodium to distal sites, data in the present study indicate that an increase in sodium excretion is not necessary for the increase in free water to occur. (See, for example, H.F. and T.T., Tables VII and IX.)

Kleeman, Epstein, and White (21) noted that maximal urine flow and $\mathrm{CF}_{\mathrm{H}_{2} \mathrm{O}}$ varied directly with total solute excretion in normal subjects. Whereas the same relationship is apparent in certain of the present studies, in some cases free water clearance was increased as total solute excretion decreased. (See, for example, Table IX, R.C., M.P. and M.G.) It is likely that the sine qua non for free water formation is delivery of proximal fluid, of which solute excretion is generally, but not always, an index.

It is not clear how the infusion of saline solutions isotonic to the plasma (at the time of infusion) during sustained water loading can "deliver" proximal filtrate to distal sites and so produce free water. The phenomenon may represent the converse of the decrease in sodium and total solute excretion regularly seen with sustained water diuresis. Whereas the GFR did not change consistently in our own experiments, it may well be that there was nonetheless an increment in filtered load with the saline infusion. The effect could be obtained without significant net increase in total body water, but the saline would of course favor 
expansion of extracellular fluid, and thus a rise in GFR (22). Diuresis induced by infusion of hypertonic saline solutions in hydropenic rats does produce a distal tubular urine more dilute than mannitol, urea, or glucose (23).

The effect of mannitol in increasing free water clearance may be attributed in part to a distal effect of unreabsorbable solute in preventing reabsorption of free water already formed (24). Whereas it is not possible from the present data to estimate the contribution of this mechanism, it appears to play a minor role in view of the effects of sodium chloride infusion just described. To explain these effects in this way, one would have to postulate selective reabsorption of the sodium at a still more distal site. Consequently, it appears more reasonable to attribute the major effect of mannitol to its action on proximal tubular fluid. This is the only mechanism which will also explain its effect in increasing potassium excretion (19).

Sustained loading with water (hexose) given intravenously demonstrated a marked difference in susceptibility to the establishment of positive fluid balance between cirrhotics and sodium-depleted normal subjects in comparison with the same normal subjects on average and high sodium intakes. Infusion for three hours at 15 to $16 \mathrm{ml}$ per minute produced positive balances of only 150 to $363 \mathrm{ml}$ (volume drunk and infused minus volume excreted) in three studies in normal subjects on a sodium intake of $100 \mathrm{mEq}$ per day (Tables VII and X). (On a $500 \mathrm{mEq}$ sodium intake, R.C. had excreted $795 \mathrm{ml}$ more than was given.) Significantly greater positive balances (912 to $2,382 \mathrm{ml}$ ) were attained in the normal subjects when sodium-depleted and in the cirrhotics (even on sodium intakes of $100 \mathrm{mEq}$ per day) because of their limitation in $\mathrm{CF}_{\mathbf{H}_{2} \mathbf{O}}$. The water load was maintained by these subjects when the infusate was changed from hexose to mannitol and their $\mathrm{C}_{\mathrm{F}_{2} \mathrm{O}}$ increased with the unreabsorbable solute. Because the normal subjects on regular and high sodium intakes were clearing free water at approximately the rate at which it was being infused, there was loss of part of the water load when the infusate was changed to mannitol. An increase in endogenous ADH activity as serum osmolality rose may have produced the precipitous falls in $\mathrm{C}_{\mathrm{H}_{2} \mathrm{O}}$ shown in Table VII. Williams and associates (25) also noted an increase in $\mathrm{C}_{\mathrm{F}_{2} \mathrm{O}}$ with the infusion of 5 per cent mannitol in one of three studies in orally hydrated subjects. It is worthy of note that the serum osmolality of the subject demonstrating the increase in $\mathrm{C}_{\mathrm{F}_{2} \mathrm{O}}$ fell from 271 to $267 \mathrm{mOsm}$ per L during the infusion of the mannitol. The other two subjects showed no change and an increase, respectively, in serum osmolality from 272 to $276 \mathrm{mOsm}$ per L while the mannitol was being infused.

In five studies of sustained "loading" in cirrhotics, mannitol produced significant increases in $\mathrm{CF}_{\mathrm{H}_{2} \mathrm{O}}$ while the fluid balance was increasing only 93 to $156 \mathrm{ml}$ (M.M. had a $385 \mathrm{ml}$ increase). In two sodium-depleted normal subjects the increase in $\mathrm{CF}_{\mathrm{H}_{2} \mathrm{O}}$ with mannitol occurred while fluid balance was decreasing by 89 and $103 \mathrm{ml}$. Thus, infusion of mannitol solutions produced an abrupt rise in $\mathrm{CF}_{\mathrm{H}_{2} \mathrm{O}}$ without much increase in and, indeed despite decreases in fluid balance (ignoring additional decrements from insensible losses).

The responses of normal subjects and of patients with cirrhosis to identical $20 \mathrm{ml}$ per $\mathrm{kg}$ loads of 5 per cent mannitol were in striking contrast; the normal subjects showed a typical osmotic diuresis with no free water, whereas the patients excreted substantial volumes of free water. It is unlikely that differences in distribution of the identical solution in normal and cirrhotic subjects could in short studies, such as these (Figure 4), account for the differences in response. Indeed, an effect of fluid volume (e.g. in decreasing ADH secretion) would appear less likely in a cirrhotic than in a normal subject. In patients with cirrhosis, the release of $\mathrm{ADH}$ appears to occur in a qualitatively normal way in response to changes in osmolality about their lower than normal level (26). With excessive proximal tubular sodium reabsorption, it is likely that a given amount of $\mathrm{ADH}$ will be more effective than it is in the presence of abundant distal tubular solute. Thus, sodium reabsorption (rather than inappropriate oversecretion of $\mathrm{ADH}$ ) could explain the initial low solute levels.

The clinical counterpart of a defect in free water clearance is, of course, the development of hyponatremia. As noted above, the patients with cirrhosis showed significantly lower serum sodium and total solute concentrations than did the normal subjects before loading (lowest row in Tables I 


\section{5\% MANNITOL INFUSION.}
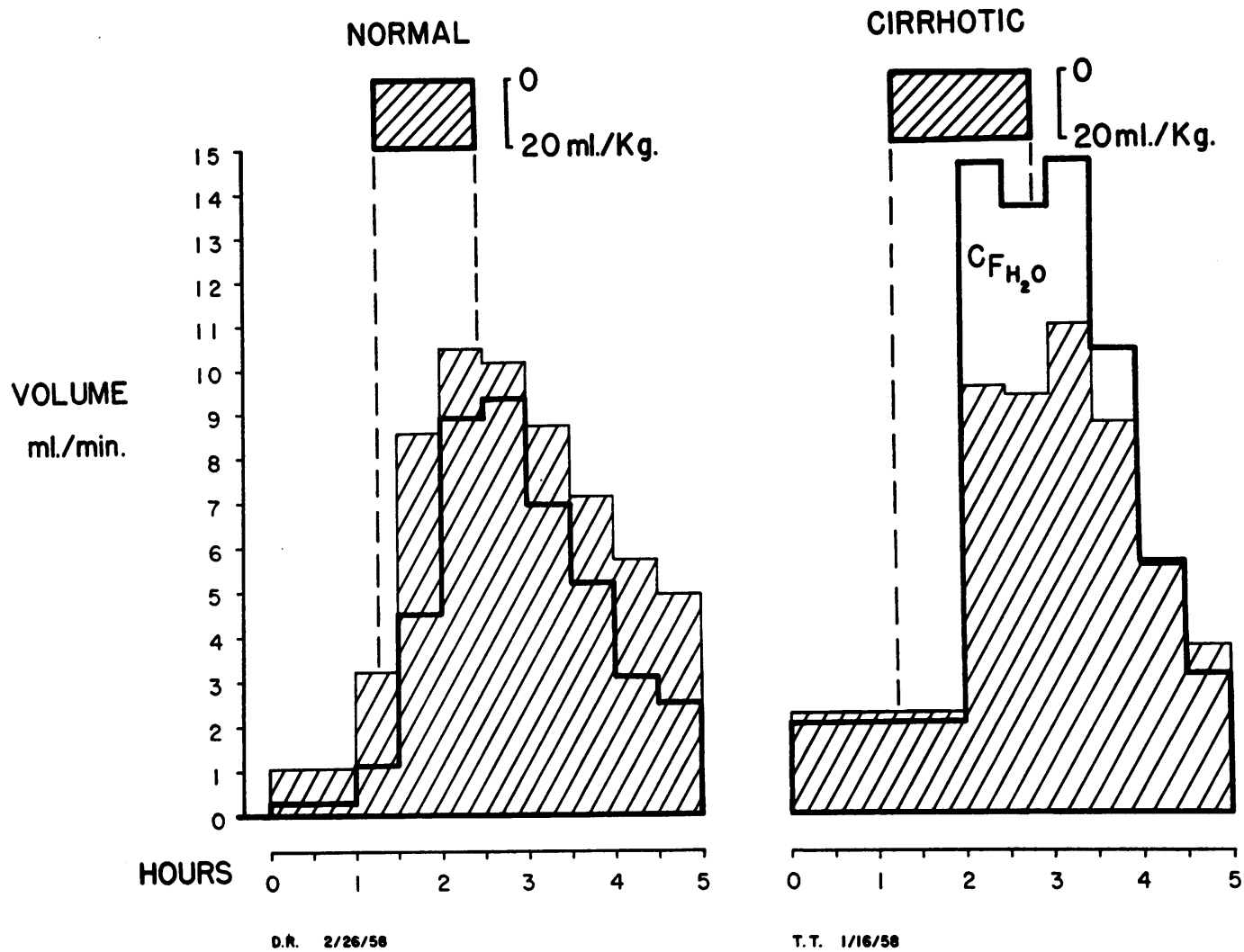

Fig. 4. Osmolal clearance (hatched areas below), free water clearance (CFh;o-Clear areas BELOW), AND URINE VOLUME (HEAVY LINES) IN A NORMAL SUBJECT AND IN A PATIENT WITH CIRRHOSIS INFUSED WITH ISOTONIC MANNITOL (HATCHED AREAS ABOVE). Note that the cirrhotic, but not the normal subject, excreted considerable free water despite the absence of free water from the infusate.

and II). Our present data show that the normal subject will himself develop the defect when sodium-depleted. Table $\mathrm{X}$ shows this counterpart for a normal subject: as sodium depletion became progressively more severe, and "maximal" free water clearance decreased, serum sodium concentration fell, and net water retention during a standard loading procedure increased (Table $\mathrm{X},{ }^{\prime} \mathrm{H}_{2} \mathrm{O}$ balance").

\section{SUMMARY AND CONCLUSIONS}

Total and "free water" diuresis were studied in patients with cirrhosis and in normal subjects before and after sodium depletion. "Acute" loading was done with $20 \mathrm{ml}$ per $\mathrm{kg}$ of $a$ ) water by mouth, b) water by vein (containing metabolizable hexose), and c) water containing mannitol by vein. Some studies were repeated with Pitressin (vasopressin aqueous) added to the infusates. Sustained loading was done with water by vein (containing metabolizable hexose) followed by water containing mannitol or saline.

Patients with cirrhosis excreted less free water than did normal subjects given identical loads by mouth or by vein. It is unlikely that the defect is primarily the result of excessive secretion or persistence of action of antidiuretic hormone, since a) all excreted some free water with loading, $b$ ) physiologic doses of vasopressin prevented this, c) the "escape" from this vasopressin occurred at a normal rate, and $d$ ) mannitol or saline infusion increased free water excretion in patients with cirrhosis and in sodium-depleted normal subjects, but decreased it in normal subjects receiving adequate sodium. The increase, which was often accompanied by increased excretion of potassium, could be produced despite decreases in total solute and sodium excretion. 
It is suggested $a$ ) that the defect in free water clearance represents relatively excessive reabsorption of sodium in proximal tubular sites where reabsorption is isosmotic with filtrate, and $b$ ) that the mannitol and saline in the infusates act by "delivering" proximal fluid to distal sites where free water is generated.

\section{REFERENCES}

1. Levy, M. S., Power, M. H., and Kepler, E. J. The specificity of the "water test" as a diagnostic procedure in Addison's disease. J. clin. Endocr. 1946, $6,607$.

2. Ralli, E. P., Leslie, S. H., Stueck, G. H., Jr., and Laken, B. Studies of the serum and urine constituents in patients with cirrhosis of the liver during water tolerance tests. Amer. J. Med. 1951, 11, 157.

3. Nelson, W. P., III, and Welt, L. G. The effects of Pitressin on the metabolism and excretion of water and electrolytes in normal subjects and patients with cirrhosis and ascites. J. clin. Invest. 1952, 31, 392.

4. Berliner, R. W., Levinsky, N. G., Davidson, D. G., and Eden, M. Dilution and concentration of the urine and the action of antidiuretic hormone. Amer. J. Med. 1958, 24, 730.

5. Orloff, J., Walser, M., Kennedy, T. J., Jr., and Bartter, F. C. Hyponatremia. Circulation 1959, 19, 284.

6. Bowman, R. L., Trantham, H. V., and Caulfield, P. A. An instrument and method for rapid, dependable determination of freezing-point depression. J. Lab. clin. Med. 1954, 43, 310.

7. Leaf, A., Bartter, F. C., Santos, R. F., and Wrong, O. Evidence in man that urinary electrolyte loss induced by Pitressin is a function of water retention. J. clin. Invest. 1953, 32, 868.

8. Wesson, L. G., Jr. Electrolyte excretion studies in the dog. Meth. med. Res. 1952, 5, 175.

9. Walser, M., Davidson, D. G., and Orloff, J. The renal clearance of alkali-stable inulin. J. clin. Invest. 1955, 34, 1520.

10. Bonsnes, R. W., and Taussky, H. H. On the colorimetric determination of creatinine by the Jaffé reaction. J. biol. Chem. 1945, 158, 581.

11. Shannon, J. A. Control of the renal excretion of water. II. The rate of liberation of the posterior pituitary antidiuretic hormone in the dog. J. exp. Med. 1942, 76, 387.

12. Lauson, H. D. The problem of estimating the rate of secretion of antidiuretic hormone in man. Amer. J. Med. 1951, 11, 135.
13. Adlersberg, D., and Fox, C. L., Jr. Changes of the water tolerance tests in hepatic disease. Ann. intern. Med. 1943, 19, 642.

14. White, A. G., Rubin, G., and Leiter, L. Studies in edema. IV. Water retention and the antidiuretic hormone in hepatic and cardiac disease. J. clin. Invest. 1953, 32, 931.

15. Lloyd, C. W. Some clinical aspects of adrenal cortical and fluid metabolism. Recent Progr. Hormone Res. 1952, 7, 469.

16. Duncan, L. E., Jr., Liddle, G. W., and Bartter, F. C. The effect of changes in body sodium on extracellular fluid volume and aldosterone and sodium excretion by normal and edematous men. J. clin. Invest. 1956, 35, 1299.

17. Wolff, H. P., Koczorek, Kh. R., and Buchborn, E. Aldosterone and antidiuretic hormone (adiuretin) in liver disease. Acta endocr. (Kbh.) 1958, 27, 45.

18. Wesson, L. G., Jr., Anslow, W. P., Jr., and Smith, $\mathrm{H}$. W. The excretion of strong electrolytes. Bull. N. Y. Acad. Med. 1948, 24, 586.

19. Davidson, D. G., Levinsky, N. G., and Berliner, R. W. Maintenance of potassium excretion despite reduction of glomerular filtration during sodium diuresis. J. clin. Invest. 1958, 37, 548.

20. Birchard, W. H., Prout, T. E., Williams, T. F., and Rosenbaum, J. D. Diuretic responses to oral and intravenous water loads in patients with hepatic cirrhosis. J. Lab. clin. Med. 1956, 48, 26.

21. Kleeman, C. R., Epstein, F. H., and White, C. The effect of variations in solute excretion and glomerular filtration on water diuresis. J. clin. Invest. 1956, 35, 749.

22. Wesson, L. G., Jr. Glomerular and tubular factors in the renal excretion of sodium chloride. Medicine (Baltimore) 1957, 36, 281, 323 and fol. lowing.

23. Gottschalk, C. W., and Mylle, M. Micropuncture study of the mammalian urinary concentrating mechanism: Evidence for the countercurrent hypothesis. Amer. J. Physiol. 1959, 196, 927.

24. Orloff, J., Wagner, H. N., Jr., and Davidson, D. G. The effect of variations in solute excretion and vasopressin dosage on the excretion of water in the dog. J. clin. Invest. 1958, 37, 458.

25. Williams, T. F., Hollander, W., Jr., Strauss, M. B., Rossmeisl, E. C., and McLean, R. Mechanism of increased renal sodium excretion following mannitol infusion in man. J. clin. Invest. 1955, 34, 595.

26. Earley, L. E., and Sanders, C. A. The effect of changing serum osmolality on the release of antidiuretic hormone in certain patients with decompensated cirrhosis of the liver and low serum osmolality. J. clin. Invest. 1959, 38, 545. 